\title{
Immunotherapy: A Novel Era of Promising Treatments for Multiple Myeloma
}

\author{
Maria Castella ${ }^{1}$, Carlos Fernández de Larrea ${ }^{1}$ and Beatriz Martín-Antonio ${ }^{1,2, *([)}$ \\ 1 Department of Hematology, Hospital Clinic, IDIBAPS, 08036 Barcelona, Spain; mcastella@clinic.cat (M.C.); \\ cfernan1@clinic.cat (C.F.d.L.) \\ 2 Josep Carreras Leukaemia Research Institute, 08036 Barcelona, Spain \\ * Correspondence: bmartina@clinic.ub.es; Tel.: +34-93-227-5400-4528
}

Received: 1 October 2018; Accepted: 13 November 2018; Published: 15 November 2018

\begin{abstract}
Multiple myeloma (MM) remains an incurable hematological malignancy characterized by clonal proliferation of malignant plasma cells in bone marrow. In the last 20 years, the introduction of autologous stem cell transplantation, followed by proteasome inhibitors and immunomodulatory agents, increased the survival of MM patients by $50 \%$. However, still a high proportion of patients relapse and become refractory, especially, high-risk patients with adverse cytogenetics where these treatment combinations have shown limited benefit. Therefore, novel strategies, such as immunotherapy, have been developed in the last few years to help improve the survival of these patients. Immunotherapy treatments include a high number of different strategies used to attack the tumor cells by using the immune system. Here, we will review the most successful immunotherapy strategies published up to date in patients with relapsed or refractory (R/R) MM, including monoclonal antibodies targeting specific antigens on the tumor cells, antibodies combined with cytotoxic drugs or Antibodies Drug Conjugates, immune checkpoint inhibitors which eliminate the barriers that damper immune cells and prevent them from attacking tumor cells, bi-specific T-cell engagers antibodies (BiTEs), bi-specific antibodies and the infusion of chimeric antigen receptor-modified $\mathrm{T}$ cells. We overview the results of clinical studies that have been presented up to date and also review pre-clinical studies describing potential novel treatments for MM.
\end{abstract}

Keywords: multiple myeloma; monoclonal antibodies; antibodies drug conjugates; immunocheckpoint inhibitors; chimeric antigen receptor (CAR)-modified T cells

\section{Multiple Myeloma, an Incurable Disease with Current Treatments}

Multiple myeloma (MM) remains an incurable hematologic malignancy responsible for $1 \%$ of all cancers and $15-20 \%$ of all hematological malignancies. The incidence in Europe is 4.5-6.0/100,000/year with a median age at diagnosis around 70 years, a mortality rate of $4.1 / 100,000 /$ year $[1,2]$ and a 5 years' survival rate of 50.7\% [3]. Unfortunately, over the past decade, the rates for new MM cases have increased an average of $0.8 \%$ per year [3]. MM is characterized by clonal expansion of malignant plasma cells in the bone marrow, which leads to an excessive production of monoclonal immunoglobulin (Ig) detectable in serum and/or urine. Associated clinical symptoms include osteolytic lesions, anemia, renal dysfunction, hypercalcemia, infections and other related organ dysfunction [4].

\section{Evolution of MM Treatment}

MM treatment has undergone a gradual series of changes over the last decades that have improved the survival of patients. However, the prognosis for MM patients is still poor in terms of curability and lifespan under treatment when compared to other hematological malignancies, such as Hodgkin lymphoma or chronic myeloid leukemia. Nowadays, a high variety of treatments 
are being evaluated in clinical trials to continue improving the survival of patients. Back in 1962, initial regimens based on a melphalan-prednisone achieved very low rates of complete remission. This was significantly improved with the incorporation of autologous stem cell transplantation (ASCT) in 1996. Afterwards, the introduction of proteasome inhibitors (PI) in 2003 [5], as well as the new generation of immunomodulatory drugs (IMiDs) in 2005, achieved an increased overall survival (OS) from 14.8 to 30.9 months [6]. Importantly, treatments based on the combination of these drugs have shown an improved survival of 50\% (44.8 vs. 29.9 months) when comparing before and after 2001 [6]. Currently, the first line of treatment for newly diagnosed MM patients consists of an induction treatment combining one PI, one IMiD and corticosteroids (dexamethasone). This induction treatment is followed by ASCT and a maintenance phase, usually based on lenalidomide. Consolidation chemotherapy regimen after ASCT, usually similar to the induction regimen, is under investigation. With these protocols, an extended survival from three to eight years was achieved $[4,7]$. Using bortezomib/lenalidomide/dexamethasone (VRD) combination followed by ASCT and 1-year lenalidomide maintenance, $58 \%$ of very good partial responses (VGPR) are achieved after induction, and after ASCT and consolidation therapy, VGPR or better achieve $70 \%$ and $87 \%$, respectively [8]. However, these PI-based regimens are not always effective, as $19 \%$ of patients do not respond to PI when used as induction treatment, and only $50 \%$ of patients with relapsed MM respond to this therapy thus becoming utterly refractory $[9,10]$. In fact, the natural history of MM is relapse until refractory disease without reaching a plateau of survival. Thus, less than $10 \%$ of patients achieve sustained complete responses (CR) beyond 5-10 years after ASCT. Moreover, relapsed or refractory $(\mathrm{R} / \mathrm{R}) \mathrm{MM}$ patients to at least 3 lines of treatment with PIs and IMiDs present only a median OS of 8 months [11]. Therefore, there is a clear unmet medical need in patients with $R / R$ MM. Novel strategies are required to improve their survival, especially in high-risk patients with adverse cytogenetics where these combinations have shown limited benefit $[12,13]$.

In this regard, as a result of a deeper understanding of the plasma cell biology, novel treatments are currently being tested in this group of patients. Recent developed drugs include the next generation of PIs (carfilzomib, ixazomib, marizomib, and oprozomib), small and targeted molecules such as histone deacetylase inhibitors, venetoclax, selinexor, Hsp90 inhibitors and PI3K/AKT/mTOR inhibitors which are currently under development. Interestingly, immunotherapy has arisen as a new modality treatment with very promising results and less toxic effects. However, side effects associated to this treatment modality, such as autoimmunity and cytokine release syndrome (CRS) still need to be ameliorated. Immunotherapy includes a high variety of treatments, such as monoclonal antibodies, bi-specific $\mathrm{T}$ cell engaging antibodies (BiTEs), bi-specific antibodies, antibody-drug conjugates (ADC), immune checkpoint inhibitors and adoptive cell immunotherapy. In this review, we will present the main immunotherapy strategies currently being used for R/R MM and other promising treatments currently being developed at a pre-clinical stage that may constitute the future of standards of clinical care for patients with MM. The most relevant studies are summarized in Table 1. 
2. Main Immunotherapy Strategies Currently Being Used or Tested for Relapsed/Refractory MM Patients

\subsection{Monoclonal Antibodies Targeting Antigens Expressed on MM Cells}

A successful and non-toxic immunotherapy treatment based on antibodies that target antigens expressed on tumor cells requires high specific and restricted expression of the target antigen. Whereas normal plasma cells express CD38, CD138, CD19 and CD45, malignant PCs loose CD45 and CD19 and usually acquire high expression of CD56 and CD117 [14,15]. At the "Ninth International Workshop on Leukocyte Antigens" a panel of surface plasma cell markers expressed in newly diagnosed MM patients was presented. This panel includes CD150 (SLAMF1), CD48 (SLAMF2), CD229 (SLAMF3), CD352 (SLAMF6), CD319 (SLAMF7 or CS1), CD272, CD86, CD200, and CD184. A later study comparing these markers in plasma cells from newly diagnosed patients, $R / R$ MM, plasma cell leukemia patients and healthy individuals concluded that SLAMF2, SLAMF3, SLAMF7 and CD272 could be other possible targets for immunotherapy [16]. Currently, only Daratumumab (anti-CD38), and Elotuzumab (anti-CS1) have received approval by the Food and Drug Administration (FDA) and European Medicines Agency (EMA) for their use in patients with MM. 
Table 1. Main Clinical trials already finished or on-going with the different immunotherapy options in relapsed/refractory multiple myeloma patients.

\begin{tabular}{|c|c|c|c|c|c|c|}
\hline $\begin{array}{l}\text { Therapeutic } \\
\text { Agent }\end{array}$ & Target & Compound & Combination & Development (Status) & Clinical Trial & Reference \\
\hline \multirow{27}{*}{$\begin{array}{l}\text { Monoclonal } \\
\text { Antibodies }\end{array}$} & \multirow{3}{*}{$\mathrm{CD} 38$} & \multirow{3}{*}{ Dara } & - & FDA approved & $\begin{array}{l}\text { NCT00574288 } \\
\text { NCT01985126 }\end{array}$ & [17-19] \\
\hline & & & Bort and Dex & Phase III (Active, not recruiting) & NCT02136134 & {$[20,21]$} \\
\hline & & & Len and Dex & Phase III (Active, not recruiting) & NCT02076009 & {$[22,23]$} \\
\hline & \multirow[t]{2}{*}{ SLAMF7 (CS1) } & \multirow[t]{2}{*}{ Elo } & - & Phase I (Enrollment halted) & $\begin{array}{l}\text { NCT00726869 } \\
\text { NCT01393964 }\end{array}$ & [24] \\
\hline & & & Len and Dex & FDA approved & $\begin{array}{l}\text { NCT00742560 } \\
\text { NCT01239797 }\end{array}$ & [25-28] \\
\hline & IL6 & Siltuximab & $\begin{array}{c}\text { Alone or with Dex } \\
\text { Bort, melpahalan and prednisone }\end{array}$ & $\begin{array}{l}\text { Phase II (Completed) } \\
\text { Phase II (Completed) }\end{array}$ & $\begin{array}{l}\text { NCT00402181 } \\
\text { NCT00911859 }\end{array}$ & $\begin{array}{l}{[29]} \\
{[30]}\end{array}$ \\
\hline & \multirow{3}{*}{$\mathrm{CD} 40$} & \multirow{3}{*}{$\begin{array}{l}\text { Lucatumumab } \\
\text { Dacetuzumab }\end{array}$} & - & Phase I (Completed) & NCT00231166 & [31] \\
\hline & & & - & Phase I (Completed) & NCT00079716 & [32] \\
\hline & & & Len and Dex & Phase I (Completed) & NCT00525447 & [33] \\
\hline & \multirow{2}{*}{ KIRs } & \multirow[b]{2}{*}{ IPH2101 } & - & Phase I (Completed) & NCT00552396 & [34] \\
\hline & & & Len & Phase I (Completed) & NCT01217203 & [35] \\
\hline & EGFR & Cetuximab & Alone or with Dex & $\begin{array}{l}\text { Phase II (Terminated, lack of recruitable } \\
\text { patients) }\end{array}$ & NCT00368121 & {$[36]$} \\
\hline & \multirow{12}{*}{ PD-1 } & \multirow{8}{*}{ Nivolumab } & \multirow{8}{*}{$\begin{array}{c}-- \\
\text { Pom and Dex or Elo and Pom and Dex } \\
\text { Elo or Elo, Pom and Dex without Nivolumab } \\
\text { Len } \\
\text { Pom and Dex or Elo, Pom and Dex } \\
\text { and Pom } \\
\text { and or Wild-type reovirus, Dex, Carf } \\
\text { Dara or Dara and Cy } \\
\text { Alone or Ipilimumab or Lirilumab or Dara, Pom and Dex vs. Dara or } \\
\text { Dara }\end{array}$} & Phase I (Recruiting) & NCT01592370 & \multirow{8}{*}{ [37] } \\
\hline & & & & Phase III (Active, not recruiting) & NCT02726581 & \\
\hline & & & & Phase II (Active, not recruiting) & NCT02612779 & \\
\hline & & & & Phase II (recruiting) & NCT03333746 & \\
\hline & & & & Phase I (terminated) & NCT03023527 & \\
\hline & & & & Phase I (recruiting) & NCT03605719 & \\
\hline & & & & Phase II (recruiting) & NCT03184194 & \\
\hline & & & & & NCT01592370 & \\
\hline & & \multirow{4}{*}{ Pembrolizumab } & Pom and Dex & Phase II (Terminated) & NCT02289222 & [38] \\
\hline & & & Len and low-dose Dex & Phase $\mathrm{Ib}$ (Active, not recruiting) & NCT02036502 & [39] \\
\hline & & & Pom and low-dose Dex & Phase III (Halted) & NCT02576977 & [40] \\
\hline & & & Len and low-dose Dex & Phase III (Halted) & NCT02579863 & [40] \\
\hline & \multirow{3}{*}{ PDL-1 } & \multirow[b]{2}{*}{ Durvalumab } & Alone or with Pom or Pom and Dex & Phase Ib (Enrollment discontinued) & NCT02616640 & \\
\hline & & & Dara or Dara, Pom and Dex & Phase II (Enrollment discontinued) & NCT02807454 & \\
\hline & & Atezolizumab & $\begin{array}{c}\text { Cobimetinib and venetoclax with and without Atezolizumab } \\
\text { Len or Dara or Dara and Len or Dara and Pom }\end{array}$ & $\begin{array}{l}\text { Phase Ib/II (recruiting) } \\
\text { Phase Ib (Recruiting) }\end{array}$ & $\begin{array}{l}\text { NCT03312530 } \\
\text { NCT02431208 }\end{array}$ & \\
\hline
\end{tabular}


Table 1. Cont.

\begin{tabular}{|c|c|c|c|c|c|c|}
\hline $\begin{array}{c}\text { Therapeutic } \\
\text { Agent }\end{array}$ & Target & Compound & Combination & Development (Status) & Clinical Trial & Reference \\
\hline \multirow{7}{*}{$\begin{array}{l}\text { Antibody-Drug } \\
\text { Conjugates } \\
\text { (ADCs) }\end{array}$} & \multirow{4}{*}{ BCMA } & & ASCT & Pre-clinical & \multirow{4}{*}{ NCT02064387 } & {$[41,42]$} \\
\hline & & GSK285791 & - & Phase I (Recruiting) & & [43] \\
\hline & & HDP-1 & - & Pre-clinical & & [44] \\
\hline & & MEDI2228 & - & Pre-clinical & & [45] \\
\hline & \multirow{2}{*}{ CD56 } & \multirow{2}{*}{$\begin{array}{l}\text { Lorvotuzumab } \\
\text { mertansine }\end{array}$} & - & Phase I (Completed) & NCT00346255 & [46] \\
\hline & & & Len and Dex & Phase I (Completed) & NCT00991562 & [47] \\
\hline & CD138 & ВТ062 & $\begin{array}{c}- \\
\text { Len and Len / Dex }\end{array}$ & $\begin{array}{l}\text { Phase I (Completed) } \\
\text { Pre-clinical }\end{array}$ & NCT01001442 & $\begin{array}{l}{[48]} \\
{[49]}\end{array}$ \\
\hline \multirow{5}{*}{ BiTEs } & \multirow{4}{*}{ BCMA-CD3 } & BI 836909 & - & Phase I (Recruiting) & NCT02514239 & [50] \\
\hline & & EM801 & & Pre-clinical & & [51] \\
\hline & & JNJ-64007957 & - & Phase I (Recruiting) & NCT03145181 & [52] \\
\hline & & PF-06863135 & - & Phase I (Recruiting) & NCT03269136 & \\
\hline & CD138-CD3 & STL001 & - & Pre-clinical & & [53] \\
\hline \multirow{3}{*}{$\begin{array}{l}\text { Bi-specific } \\
\text { Antibodies }\end{array}$} & NKG2D-CS1 & CS1-NKG2D biAb & - & Pre-clinical & & [54] \\
\hline & BCMA & BiFab-BCMA & & Pre-clinical & & [55] \\
\hline & CS1 & BiFab-CS1 & & Pre-clinical & & [55] \\
\hline \multirow{12}{*}{ CARs } & \multirow{4}{*}{ BCMA } & Anti-BCMA CAR T cells & - & Phase I (Active, not recruiting) & NCT02215967 & {$[56,57]$} \\
\hline & & bb2121 CAR & - & Phase I (Recruiting) & NCT02658929 & [58] \\
\hline & & LCAR-B38M CAR-T & - & Phase I/II (Enrolling by invitation) & NCT03090659 & [59] \\
\hline & & CART-BCMA & - & Phase I (Active, not recruiting) & NCT02546167 & {$[60]$} \\
\hline & CD19 & CTL019 & ASCT & Phase I (Completed) & NCT02135406 & {$[62,63]$} \\
\hline & CD19/BCMA & $\begin{array}{c}\text { Bispecific CD19/BCMA } \\
\text { CAR }\end{array}$ & ASCT & Phase I/II (Recruiting) & NCT03455972 & \\
\hline & \multirow[b]{2}{*}{ CD138 } & CART138 & - & Phase I/II (Unknown) & NCT01886976 & \multirow[t]{2}{*}{ [64] } \\
\hline & & ATLCAR.CD138 Cells & - & Phase I (Recruiting) & NCT03672318 & \\
\hline & CD38 & anti-CD38 CAR & - & Pre-clinical & & {$[65,66]$} \\
\hline & CD44v6 & Anti- CD 44v6 CAR & - & Pre-clinical & & [67] \\
\hline & Integrin $\beta 7$ & MMG49 CAR & - & Pre-clinical & & [68] \\
\hline & CS1 & CS1-CAR T cells & - & Pre-clinical & & {$[69,70]$} \\
\hline
\end{tabular}

Bort: Bortezomib, Dex: dexamethasone, Len: Lenalidomide, Pom: Pomalidomide, Elo: Elotuzumab, Carf: Carfilzomib, Dara: Daratumumab, Cy: Cyclophosphamide, ASCT: Autologous stem cell Transplantation, FDA: Food and Drug Administration. 
Daratumumab (Darzalex) is a monoclonal antibody that recognizes CD38 and induces tumor cell death not only through complement-dependent cytotoxicity (CDC) and antibody-dependent cell-mediated cytotoxicity (ADCC) [71] but also through antibody-mediated cellular phagocytosis [72]. In 2016, the FDA approved daratumumab as monotherapy for the treatment of R/R MM patients who received $\geq 3$ prior treatments that included a PI and an IMiD or those who were double refractory to a PI and an IMiD [73]. This approval was based on initial results of the GEN501 [17] and SIRIUS studies [18] showing OR of $36 \%$ and $29 \%$ after a median follow-up of 16.9 months and 9.3 months, respectively. Importantly a deepening of response over time that included CRs and stringent $\mathrm{CR}$ (sCRs) was also observed. Afterwards, an updated analysis of these patients, showed OR of 31.1\%, and a median duration of response of 7.6 months, with a progression free survival (PFS) and OS of 4 and 20.1 months, respectively [19]. Daratumumab has also been tested in combination with other agents. Combination of daratumumab with bortezomib and dexamethasone has shown longer PFS than bortezomib and dexamethasone alone, with OR of $82.9 \%$ vs. $63.2 \%$, and CR or better of $19.2 \%$ vs. $9 \%$. At a median follow-up of 7.4 months, the median PFS was not reached in the daratumumab group, being 7.2 months in the control group. However, the combination of daratumumab with other drugs was also associated with some grade 3 and 4 adverse events [20]. An updated analysis of this study showed that at a median of 19.4 months, daratumumab plus bortezomib and dexamethasone prolonged PFS (16.7 vs. 7.1 months) and improved the OR (83.8\% vs. 63.2\%) [21]. Daratumumab has also been tested in combination with lenalidomide and dexamethasone. A phase III study with $569 \mathrm{R} / \mathrm{R}$ MM patients showed that daratumumab improved PFS at 12 months ( $83.2 \%$ vs. $60.1 \%)$, OR (92.9\% vs. $76.4 \%$ ), and higher CR or better ( $43.1 \%$ vs. $19.2 \%$ ) were obtained. Unfortunately, again, daratumumab associated with higher grade 3 and 4 adverse events including neutropenia ( $51.9 \%$ vs. $37.0 \%$ ) and higher rate of infection (28.3 vs. $22.8 \%$ ) [22]. An updated analysis of this study at 25.4 months showed that daratumumab plus lenalidomide/dexamethasone vs. lenalidomide/dexamethasone alone prolonged PFS (median not reached vs. 17.5 months). The OR was $92.9 \%$ vs. $76.4 \%$ and CR or better was $51.2 \%$ vs. $21.0 \%$. PFS was significantly prolonged for daratumumab group, a benefit also maintained in high-risk patients (PFS of 22.6 vs. 10.2 months) [23]. Finally, among all treatment combinations in R/R $\mathrm{MM}$, a recent meta-analysis of 24 randomized controlled trials performed in published studies up to June 2017 showed that the combination of daratumumab, lenalidomide, and dexamethasone achieved better efficacy than other regimens in terms of time to progression and PFS [74]. Despite these positive results, loss of expression of the target antigen (CD38) remains as an important problem associated to daratumumab treatments, as tumor cells stop responding to the therapy. Different mechanisms have been suggested to be responsible for antigen loss, such as uptake of CD38 by monocytes or granulocytes through trogocytosis [75] or through release in microvesicles [76]. On the other side, loss of CD38 has been described to decrease the adenosine effect and create a less immunosuppressive environment [77], which could facilitate further therapies. Additional studies are required to elucidate the consequences of loss of target antigen and to continue improving clinical results.

Elotuzumab (EMPLICITI) is a humanized monoclonal antibody which recognizes SLAMF7 or CS1. SLAM family of receptors are type I transmembrane glycoproteins belonging to the Ig superfamily, which are adhesion molecules expressed on different hematopoietic cells [78]. CS1 was described to be highly expressed on MM cells and normal plasma cells. Some other hematological cells, such as Natural Killer (NK) cells, some T cell subsets and dendritic cells, also show low levels of CS1 expression [79]. Interestingly, elotuzumab has shown little or no direct cytotoxic activity on MM cells in vitro. However, CS1 is a positive regulator of NK cell activation [80]. In this way, elotuzumab anti-MM activity has been associated to activation of ADCC mediated by NK cells and also to enhanced NK cytotoxicity independent of ADCC [81,82]. Moreover, elotuzumab promotes antibody-dependent cellular phagocytosis of macrophages contributing to the elotuzumab antitumor potency [83].

In patients with $\mathrm{R} / \mathrm{R} \mathrm{MM}$, elotuzumab has not shown objective responses as a single agent, achieving only $26.5 \%$ of stable disease at the highest dose tested and showing mild to moderate adverse events [24]. However, a higher efficacy was obtained in combination regimens. In a phase I 
study including 29 patients with R/R MM, elotuzumab with lenalidomide and dexamethasone showed $82 \%$ of OR and median time to progression was not reached for patients treated with elotuzumab after a median of 16.4 months [25]. A subsequent phase 3 study (ELOQUENT-2 study) comparing elotuzumab with lenalidomide and dexamethasone vs. lenalidomide and dexamethasone, showed that after a median of 24.5 months, PFS at 2 years was $41 \%$ for elotuzumab vs. $27 \%$ in the control group. Median PFS was 19.4 vs. 14.9 months in the control group and OR was $79 \%$ vs. $66 \%$ in the control group [26]. These results led to the FDA approval of elotuzumab for use in combination with lenalidomide and dexamethasone for treatment of R/R MM patients, in November 2015 [84,85]. An updated analysis at 3 and 4 years of the ELOQUENT-2 study concluded that risk of disease progression/death was reduced by $27 \%$ in the Elotuzumab arm, and OS and PFS demonstrated a trend in favour of elotuzumab, showing at $1,2,3$ and 4 -years an OS of: $91 \%$ vs. $83 \%, 73 \%$ vs. $69 \%, 60 \%$ vs. $53 \%$ and $50 \%$ vs. $43 \%$. PFS at $1,2,3$ and 4 -year was of: $69 \%$ vs. $57 \%, 41 \%$ vs. $28 \%, 27 \%$ vs. $19 \%$ and $21 \%$ vs. $14 \%$. Adverse events were similar in both groups $[27,28]$. Moreover, high-risk patients had a $36 \%$ reduction in the risk of progression/death when treated with Elotuzumab.

B cell maturation antigen (BCMA) is the tumor necrosis factor superfamily member 17 , a transmembrane glycoprotein involved in the regulation of B cell maturation and survival $[86,87]$. BCMA is an ideal target for MM due to its specific and restricted expression in MM cells. The main success of BCMA in immunotherapy has occurred in the field of chimeric antigen receptor (CAR) $\mathrm{T}$ cell therapy, as discussed later. However, in the field of Antibody Drug Conjugates (ADC), three compounds are being tested: GSK2857916, HDP-1 and MEDI2228. GSK2857916 is a humanized afucosylated anti-BCMA antibody coupled to maleimidocaproy and monomethyl auristatin, which has shown potent anti-MM activity, in part by triggering ADCC and antibody-dependent cellular-mediated phagocytosis. Its effect is enhanced with lenalidomide [88]. When testing GSK2857916 as monotherapy for R/R MM patients in a phase I study, it obtained $60 \%$ of OR with a median PFS of 7.9 months [43]. HDP-1 is another anti-BCMA antibody with a payload of maleimide-amanitin which has demonstrated potent anti-MM activity in vitro and in murine and Cynomolgus monkeys models [44]. Finally, MEDI2228 is an ADC composed of a fully human anti-BCMA antibody conjugated to a pyrrolobenzodiazepine dimer with potent in vitro and in vivo anti-MM activity in murine models [45].

Other monoclonal antibodies have been tested in patients with $\mathrm{R} / \mathrm{R} \mathrm{MM}$ with limited success in initial studies. These include antibodies against IL6, CD56, CD138 and CD40. IL6 enhances the survival of MM cells and limits the benefits of other MM treatments [89]. Therefore, siltuximab (CNTO 328), a monoclonal antibody against IL6 was analyzed in a Phase II study. Siltuximab alone did not show any benefit and very limited benefit was also obtained when in combination with dexamethasone [29]. A lack of benefit of this novel drug was confirmed in an additional Phase II study that analyzed siltuximab in combination with bortezomib, melphalan and prednisone [30].

Lorvotuzumab is a humanized monoclonal antibody against CD56. CD56 is highly expressed in malignant plasma cells [90] but also in other immune cells, such as NK cells. Lorvotumumab as a single agent showed limited response [46]. Further studies analyzed Lorvotumumab as an ADC combining it with maytansine (named Lorvotuzumab mertansine). This ADC was tested in combination with lenalidomide and dexamethasone in a Phase II study in 2014. Limited responses were obtained with OR of $56.4 \%$. Neurotoxicity was detected as the most common adverse event [47]. Due to its reduced benefit no further studies have been conducted.

CD138 is a member of the Syndecan family with a role in cell-cell contacts. It participates in the regulation of various processes such as cell proliferation, apoptosis, metastasis and angiogenesis. It is highly expressed in MM cells, but also in epithelial tissues (reviewed in [91]). A murine/human chimeric antibody against CD138 was tested as an ADC, by conjugating the antibody to the maytansinoid drug DM4 (named Indatuximab ravtansine or BT062). BT062 has shown anti-MM activity in vitro and in murine models [92]. However, as a single-agent in MM patients, BT062 did not achieve responses [48]. In combination with lenalidomide and lenalidomide/dexamethasone an additive or synergistic anti-MM activity was shown in murine models [49]. CD138 has also been 
used in pre-clinical models of radioimmunotherapy, an approach which couples an antibody with a radionuclide that has a cytotoxic effect. This combination was shown to delay disease progression in xenograft MM murine models [93].

Lucatumumab and dacetuzumab are two monoclonal antibodies against CD40 which have been tested in patients with R/R MM. Lucatumumab is a human monoclonal antibody that was evaluated in a phase 1 study in $28 \mathrm{R} / \mathrm{R}$ MM patients. The therapy was being well tolerated. However, only one patient ( $4 \%$ ) maintained a PR for $\geq 8$ months [31]. Dacetuzumab is a humanized monoclonal antibody which was tested in 44 patients, and only $20 \%$ of patients achieved stable disease [32]. Dacetuzumab was also tested in combination with lenalidomide and dexamethasone and only limited responses were obtained with $39 \%$ of OR [33]. No further studies have been published in MM patients with these antibodies.

IPH2101 is a human monoclonal antibody against inhibitory killer-cell immunoglobulin-like receptors (KIRs) on NK cells that inhibit the cytotoxic activity of NK cells [94]. By blocking these inhibitory signals, NK cells should be activated against MM cells. Unfortunately, phase I studies in R/R MM patients using IPH2101, both as a single agent or in combination with lenalidomide, failed to obtain responses. As a single agent, IPH2101 was well tolerated and no OR were detected [34]. In combination with lenalidomide, in 15 patients, IPH2101 achieved only $33.3 \%$ of OR with a median PFS of 24 months [35].

Cetuximab, a chimeric human-murine antibody against EGFR was also tested in a Phase II study in R/R MM patients, as single agent and in combination with dexamethasone. However, no ORs were detected in combination with dexamethasone. $47 \%$ of patients achieved stable disease [36].

\subsection{Bi-Specific T-Cell Engagers Antibodies (BiTEs) and Bi-Specific Antibodies for R/R MM Patients}

BiTEs have shown promising results in the treatment of R/R MM in pre-clinical studies. BiTEs are designed to bind a tumor cell and an immune cell by engaging usually CD3 with an antigen expressed in the tumor cell. Consequently, the T cell becomes activated and attacks the target cell [95]. There are different BiTEs targeting BCMA and CD3 (BI 836909, EM801 and JNJ-64007957), which have shown potent anti-MM activity in vitro and in vivo murine and monkey models of MM [50-52]. These BiTEs and also PF-06863135 are currently being tested in clinical trials in patients with MM (NCT02514239, NCT03145181, NCT03269136 and NCT03269136). Other promising BiTEs, which are at a pre-clinical stage, include one combining CD138 and CD3, which has shown potent anti-MM activity in vitro and in murine models [53].

Also bi-specific antibodies are being tested for the treatment of MM. NKG2D is an activating receptor expressed on NK cells, $\mathrm{CD}^{+} \mathrm{T}$ cells, $\gamma \delta \mathrm{T}$ cells and NKT cells. Simultaneous targeting of NKG2D and CS1 should engage both innate and adaptive immune cells to target MM cells. A bi-specific antibody combining NKG2D with CS1 has shown in vitro and in vivo anti-MM activity [54]. BiFabs are bi-specific antibodies which target two different epitopes on the same protein. BiFabs against BCMA and CS1 have been tested and compared, demonstrating that BiFab-BCMA had higher anti-MM activity than BiFab-CS1. Moreover, BiFab-BCMA anti-MM activity was comparable to that of CART-BCMA cells in vitro and in vivo [55].

\subsection{Monoclonal Antibodies Targeting Immune Checkpoints between Immune and MM Cells}

Immune checkpoints are negative signals established between immune and tumor cells that hamper immune cells and prevent them from eliminating malignant cells. Allison J. pioneered studies blocking immune checkpoints and demonstrated enhanced anti-tumor responses. These studies led to the development of very successful cancer therapies, especially in solid tumors [96,97]. Antibodies such as ipilimumab, which blocks CTLA-4, pembrolizumab and nivolumab, which block PD-1 in T cells, and atezolizumab, durvalumab and avelumab, which block PD-L1 on tumor cells, have been developed and approved by the FDA for solid tumors [98-102]. However, targeting immune checkpoints has not been very successful in MM as of yet. 
Pre-clinical studies showed that immune and MM cells from patients present higher expression of PD-1 and PD-L1 than healthy individuals, and that the blockade of PD-1/PD-L1 abrogates MM growth, which is further enhanced with lenalidomide combination [103]. Moreover, in murine MM models, low dose irradiation, as lymphodepletive chemotherapy, plus PD-L1 blockade provided synergistic anti-tumor efficacy [104]. However, when these inhibitors were tested in patients with MM, results were disappointing. As single agents, PD-1 inhibitors were not successful. Whereas pembrolizumab has not been tested as a single agent in R/R MM patients, nivolumab was tested in $27 \mathrm{R} / \mathrm{R} M \mathrm{MM}$ patients (NCT01592370). OR occurred only in one patient (4\%) and moreover, adverse events occurred in $52 \%$ with $19 \%$ of them being serious adverse events [37]. Afterwards, combination studies with IMiDs showed higher efficacy but also higher toxicity. Pembrolizumab combined with pomalidomide and dexamethasone in a Phase II trial with $48 \mathrm{R} / \mathrm{R}$ MM patients showed severe adverse events in $40 \%$ of patients. ORs were of $60 \%$, including $8 \%$ of stringent CR/CR, $19 \%$ VGPR and $33 \%$ PR. At median follow-up of 15.6 months, PFS was 17.4 months and OS was not reached [38]. Pembrolizumab was also combined with lenalidomide and low-dose dexamethasone in a phase I study including 51 patients. $65 \%$ of patients experienced high grade adverse events. Only 40 patients continued in the study, obtaining $50 \%$ of OR and a median duration of response of 11.3 months [39]. However, later studies in a phase III trial comparing pembrolizumab, pomalidomide and low dose dexamethasone vs. pomalidomide and dexamethasone (NCT02576977) [105], and a second study in newly diagnosed MM patients comparing pembrolizumab with lenalidomide and low dose dexamethasone vs. lenalidomide and low dose dexamethasone (NCT02579863) [106] reported a high number of deaths related to the high toxicity of the treatment. Non-disease progression causes of death identified in the pembrolizumab arm included intestinal ischemia, pulmonary embolism, pneumonia, sudden death, large intestine perforation, myocarditis, Stevens-Johnson syndrome, myocardial infarction, pericardial hemorrhage, cardiac failure, cardio-respiratory arrest, respiratory tract infection, neutropenic sepsis, sepsis, multiple organ dysfunction and respiratory failure. Consequently, both studies were halted in 2017 [40].

Nivolumab, another PD-1 inhibitor, is currently being used in combination with different IMiDs at several clinical trials (NCT02726581, NCT02612779, NCT03333746, NCT03023527, NCT03605719, NCT03184194, NCT01592370). However, clinical results are not available yet. Additional information regarding these clinical trials is summarized in Table 1. In addition, PD-L1 inhibitors (durvalumab and atezolizumab) are also being assessed in R/R MM patients in different clinical trials. Durvalumab is being evaluated in combination with different IMiDs, dexamethasone and daratumumab (NCT02616640, NCT02807454, NCT03000452); and atezolizumab with cobimetinib and venetoclax (NCT03312530), and with different combinations of IMiDs and daratumumab (NCT02431208). Additional information is summarized in Table 1.

\subsection{Chimeric Antigen Receptor (CAR)-T Cell Immunotherapy}

Genetically modifying autologous $\mathrm{T}$ cells to express chimeric antigen receptors (CARs) thus redirecting them to eliminate tumor cells or other harmful cells is a new and revolutionary therapeutic modality for cancer treatment [62,107-114]. CARs are composed of an extracellular region responsible for binding to a particular antigen and an intracellular region that promotes $\mathrm{T}$ cell cytotoxic activity and proliferation. CAR binding to the selected antigen is usually mediated by a single chain variable fragment ( $\mathrm{scFv}$ ) of a monoclonal antibody and is MHC-independent. This scFv is combined with an intracellular co-stimulatory domain (usually CD28 or 4-1BB) and a pro-activator cytotoxic domain (CD3乙) [115-117].

Anti-CD19 CAR is a paradigm for CAR $\mathrm{T}$ cell therapy. It has shown impressive response rates in $\mathrm{CD} 19^{+} \mathrm{R} / \mathrm{R}$ hematological malignancies, especially in B-cell acute lymphoblastic leukemia (B-ALL), non-Hodgkin's lymphoma (NHL), and chronic lymphocytic leukemia (CLL). Response rates range from $50-85 \%$ depending on the type of B-cell malignancy and CAR construct, with quite remarkable DFS and OS. In terms of safety, patients who respond to anti-CD19 therapy usually develop persistent B-cell aplasia, which is then treated with gamma globulins as a replacement 
therapy, and transitory cytokine release syndrome (CRS), manageable in the vast majority of cases. However, some patients experience severe CRS with hypotension, pulmonary edema, coagulopathy, vascular leak and neurotoxicity [114,117-120]. This success led to the rapid development of CAR $\mathrm{T}$ cell field. The FDA and European Medicines Agency (EMA) have already approved two CAR19 products (tisagenlecleucel and axicabtagene ciloleucel) for the treatment of B-ALL and large B-cell lymphoma (DLBCL). Other CARs for hematologic and solid tumors are currently being developed at the pre-clinical or clinical stage. The success of new CAR T cell therapies relies on selecting the right antigen to target. The antigen should be expressed broadly in tumors of a given type, but should not be present in healthy tissues, as to avoid off-target effects and associated toxicity. Therefore, the number of antigens to target is limited. As we describe below, new approaches include dual targeting, targeting cancer neoantigens or cancer-specific protein conformations expressed on the surface of cancer cells. Here, we describe the present and future of CAR T cell therapies for MM. There are currently 32, completed or on-going, clinical trials involving CAR T cell therapy in MM. The vast majority of them are evaluating the efficacy of anti-BCMA CAR and a few assessing anti-CD19 or anti-CD138 CAR.

\subsubsection{CAR BCMA}

As previously mentioned, BCMA constitutes an ideal candidate for targeted MM therapies, as its expression is restricted to plasma cells, being the expression in MM cells higher than in normal PCs $[121,122]$. Initial studies using CAR BCMA in R/R MM rapidly placed CAR BCMA on the spotlight of new therapies being developed for the treatment of this disease. The first clinical study, using a 2nd generation CAR with CD28 co-stimulation, described CRs in several patients and no toxicities associated with off-target effects on other tissues. This dose-escalating clinical trial also determined that a much higher dose (about 10 times more CARTBCMA than CART19) was required to eliminate the tumor. At a $9 \times 10^{6}$ CAR T cell $/ \mathrm{kg}$ dose, the OR rate was $81 \%$ and the median event-free survival was 31 weeks $[56,57]$. Since then, several centers have put their efforts in developing new CAR BCMA constructs and moving them into clinic. Preliminary results with a 2nd generation CAR using 4-1BB co-stimulation (bb2121 CAR) by Bluebird and Celgene, announced OR of $100 \%$, at a dose of $15-80 \times 10^{7}$ CAR T cells or more [58]. Also LCAR-B38M CAR-T from Nanjing Legend Biotech, which has the particularity of being based on a bi-specific antibody that binds BCMA through two different epitopes, has reported $100 \%$ OR and 74\% CR [59]. Finally, Novartis has also presented preliminary results of their clinical trial using their CART-BCMA, with $5 / 6$ patients responding at $10^{8}$ cell dose [60]. Lastly, a new CAR BCMA with successful preclinical results in a mice model (unpublished data) has been developed at our institution (Hospital Clinic, Barcelona). A new Phase I clinical Trial will start in 2019 using this CAR.

Thus, preliminary results using CAR BCMA in the clinic demonstrate that CARs targeting other antigens than CD19 are effective against hematological malignancies. In fact, CAR BCMA and CAR19 seem to be comparable in terms of efficacy and safety, for the treatment of their respective indications. In terms of safety, adverse effects observed with CAR BCMA include CRS in about 75\% of patients (10-25\% of patients presenting grade $3-4$ CRS) and $10 \%$ or less of patients presenting neurotoxicity. In all cases, CRS or neurotoxicity resolved, spontaneously or following tocilizumab administration [56-60]. An additional problem which has been observed after CAR BCMA, is the loss of expression of the target antigen [121,123], which has been observed also after CAR 19 treatment [124]. In this sense, we have observed that BCMA expression in MM cells is not stable and it shows a continuous release and recycling into the extracellular milieu (Figure 1). As a possible option to avoid it, the use of $\gamma$-secretase inhibitors will avoid the effect of $\gamma$-secretase which directly cleaves BCMA and releases soluble BCMA [125]. 


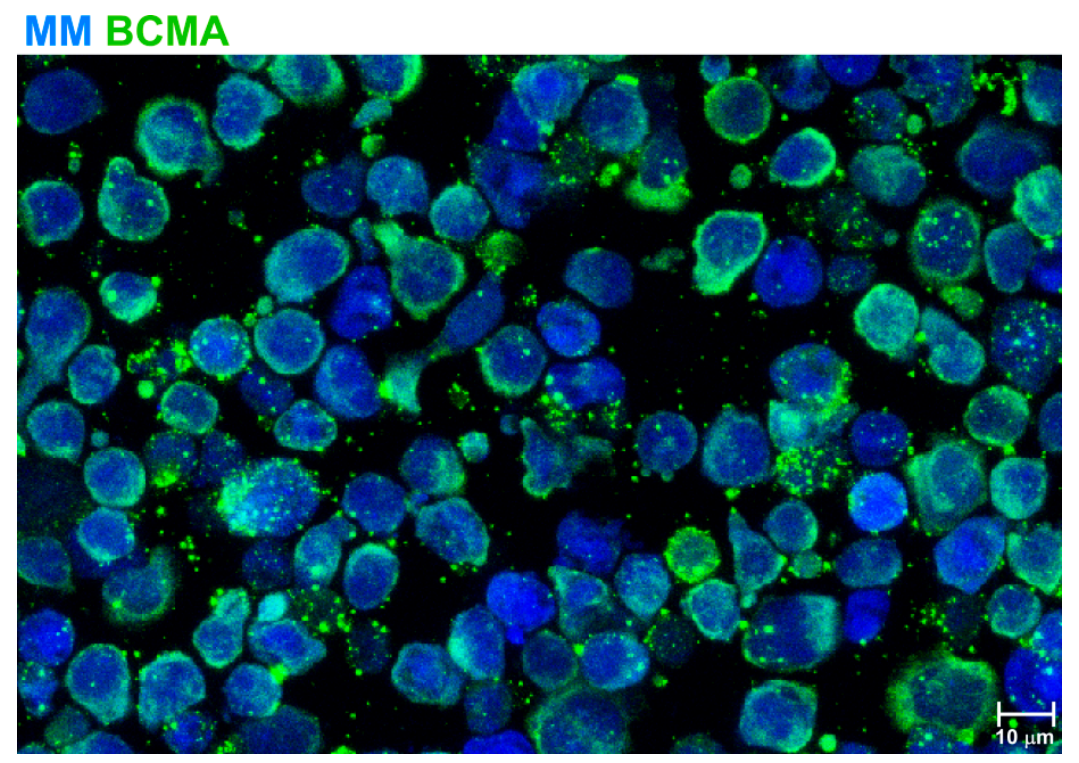

Figure 1. BCMA expression and release from multiple myeloma (MM) cells: MM cells (in blue) stained for BCMA (green). BCMA can be released in vesicles, and shows a non-uniform expression among all MM cells which changes over time. Scale bar is indicated.

Several other CARs targeting BCMA have been developed at the pre-clinical level. One that deserves especial mentioning is a CAR based on the natural BCMA ligand, APRIL [61]. APRIL is a proliferating ligand specific for two receptors expressed specifically in MM cells, BCMA and TACI. TACI expression is not as broad as BCMA, but is expressed in $78 \%$ of primary MM cells. Pre-clinical data show that APRIL-CAR is as potent as BCMA-CAR in mediating MM killing and may prevent antigen escape by targeting two different proteins. A new clinical trial (NCT03287804) using APRIL-CAR is currently recruiting patients in Europe.

\subsubsection{CAR 19}

CD19 is not expressed in the predominant population of most of MM cells. Although still controversial, several groups have reported that CD19 expression is associated with a minor subset of malignant cells with a less differentiated phenotype that may act as cancer stem cells [126]. In an attempt to explore the efficacy of CART19 in the treatment of MM, patients received CART19 therapy after ASCT. However, this therapy did not show very promising results, as the time to relapse was not prolonged in $8 / 10$ patients $[62,63]$. Moreover, a clinical trial at the First Affiliated Hospital, Soochow University, China (NCT03455972) is currently recruiting patients to test efficacy of a bi-specific CD19/BCMA CAR post-ASCT.

\subsubsection{CAR CD138}

As previously mentioned, CD138 is highly expressed in MM cells, but also in epithelial tissues (reviewed in [91]). Therefore, CD138 might not be an ideal target due to potential associated toxicity of the treatment. However, a study treating $5 \mathrm{MM}$ patients with CAR CD138 did not report significant toxicities [64], although the efficacy of the treatment was limited, with only stable disease observed in 4 out of 5 patients that eventually progressed [64]. Additional studies are required to assess the potential of CAR CD138 for the treatment of MM. In these lines, another clinical trial using this CAR will shortly start at Lineberger Comprehensive Cancer Center, Chapel Hill, NC (NCT03672318).

\subsubsection{Other CARs Being Developed at the Pre-Clinical Stage}

CD38 has been proposed as a candidate target for CAR T cell therapy in MM. CD38 is expressed in MM cells and also in other hematopoietic cells, especially NK cells and monocytes, which might 
lead to high off-target effects. Surprisingly, monoclonal antibody therapies against CD38 in MM patients showed good efficacy and no toxicity associated to off-target effects [17]. However, in vitro data showed that anti-CD38 CAR T cell therapy might present a higher level of toxicity against normal hematopoietic cells [65]. In order to make anti-CD38 CAR T cell therapy safer, several strategies have been proposed and developed in pre-clinical studies, such as designing a low-affinity anti-CD38 CAR [65] or incorporating a caspase-9-based suicide gene to eliminate CAR T cells when required [66].

CD44 is a cell surface adhesion protein expressed in hematological and epithelial cells. It is highly expressed in tumor cells and has a critical role in cancer initiating cells [127]. The expression pattern of CD44v6 splicing isoform is more restricted being absent in hematopoietic stem cells (HSCs) and showing lower level of expression in other hematological cells and keratinocytes [128,129]. An anti-CD44v6 CAR has been developed for the treatment of MM and AML. Pre-clinical data show anti-MM and anti-AML activity and no cytotoxic activity against HSC and keratinocytes. However, cytotoxic activity against circulating monocytes was observed. To circumvent the potential off-target effects of this CAR, a suicide mechanism based on caspase- 9 was introduced in the CAR T cells. This system was validated in vitro [67].

Hosen and colleagues described the use of integrin $\beta 7$ as a potential target for MM [68]. This target was identified using an unbiased screen of $>10,000$ hybridomas against MM tumor cells. Interestingly, the mAb identified (MMG49) recognizes only a cancer-specific conformation of integrin $\beta 7$. Therefore, even integrin $\beta 7$ is expressed in non-tumor cells, the CAR developed is highly specific for MM. Pre-clinical data shows efficacy of MMG49 CAR in vitro and in vivo.

Another antigen being explored as a target for anti-MM therapy is CS1. Pre-clinical studies show anti-MM activity of CS1-CAR T cells in mouse xenograft models, with CS1-CAR-T cells alone [69], or in combination with IMIDs [70]. New phase I clinical trials are expected to open shortly to test the potential of these new CARs as anti-MM therapies in the clinic.

\section{Concluding Remarks}

To summarize, the introduction of ASCT, PIs and IMiDs in the treatment of MM patients have improved significantly the outcome of patients with MM. However, there is a proportion of R/R MM patients to these treatments with a poor outcome where novel strategies are required. The revolution of immunotherapy in cancer treatment in the last years is a field which is being incorporated to the treatment of MM. Among the different types of immunotherapy, the introduction of monoclonal antibodies targeting CD38 (daratumumab) and CS1 (elotuzumab) in combination with IMiDs or bortezomib has significantly improved the outcome of patients with R/R MM. Other monoclonal antibodies targeting IL6, CD56, CD138 and CD40 were tested but, unfortunately, did not show any benefit or just limited responses were observed. Moreover, immunocheckpoint inhibitors have not shown a beneficial effect in MM patients, and additionally, high toxicities were detected. In the field of CAR-modified T cells, BCMA has proven to be the star among other CARs tested in MM and very promising clinical results are expected. CAR T cells targeting CD138 have shown limited responses, however studies in patients are still at initial stages. Other CARs still at pre-clinical phases which could show promising clinical results include CARs against CD38, CD44v6, integrin $\beta 7$ and CS1. It is expected that in the next decade, as new alternatives appear, novel combination of treatments will be tested and hopefully will lead to higher complete remission rates and prolonged survival in patients with MM along with the lowest possible toxicity.

Author Contributions: M.C. and B.M.-A. wrote the manuscript. All the authors reviewed the manuscript.

Acknowledgments: Institute of Health Carlos III (project: PI14/00798 and PI17/01043) provided funding for all studies. All authors declare no conflicts of interests.

Conflicts of Interest: All authors declare there is no conflict of interests. 


\section{References}

1. Moreau, P.; San Miguel, J.; Sonneveld, P.; Mateos, M.V.; Zamagni, E.; Avet-Loiseau, H.; Hajek, R.; Dimopoulos, M.A.; Ludwig, H.; Einsele, H.; et al. Multiple myeloma: ESMO Clinical Practice Guidelines for diagnosis, treatment and follow-up. Ann. Oncol. 2017, 28, iv52-iv61. [CrossRef] [PubMed]

2. Kumar, S.K.; Callander, N.S.; Alsina, M.; Atanackovic, D.; Biermann, J.S.; Chandler, J.C.; Costello, C.; Faiman, M.; Fung, H.C.; Gasparetto, C.; et al. Multiple Myeloma, Version 3.2017, NCCN Clinical Practice Guidelines in Oncology. J. Natl. Compr. Cancer Netw. 2017, 15, 230-269. [CrossRef]

3. Cancer Stat Facts: Myeloma. National Cancer Institute Surveillane, Epidemiology, and End Results Program Web Site. 2017. Available online: http://seer.cancer.gov/statfacts/html/mulmy.html (accessed on 24 January 2017).

4. Palumbo, A.; Anderson, K. Multiple myeloma. N. Engl. J. Med. 2011, 364, 1046-1060. [CrossRef] [PubMed]

5. Twombly, R. First proteasome inhibitor approved for multiple myeloma. J. Natl. Cancer Inst. 2003, 95, 845. [CrossRef] [PubMed]

6. Kumar, S.K.; Rajkumar, S.V.; Dispenzieri, A.; Lacy, M.Q.; Hayman, S.R.; Buadi, F.K.; Zeldenrust, S.R.; Dingli, D.; Russell, S.J.; Lust, J.A.; et al. Improved survival in multiple myeloma and the impact of novel therapies. Blood 2008, 111, 2516-2520. [CrossRef] [PubMed]

7. Anderson, K.C. Oncogenomics to target myeloma in the bone marrow microenvironment. Clin. Cancer Res. 2011, 17, 1225-1233. [CrossRef] [PubMed]

8. Roussel, M.; Lauwers-Cances, V.; Robillard, N.; Hulin, C.; Leleu, X.; Benboubker, L.; Marit, G.; Moreau, P.; Pegourie, B.; Caillot, D.; et al. Front-line transplantation program with lenalidomide, bortezomib, and dexamethasone combination as induction and consolidation followed by lenalidomide maintenance in patients with multiple myeloma: A phase II study by the Intergroupe Francophone du Myelome. J. Clin. Oncol. 2014, 32, 2712-2717. [CrossRef] [PubMed]

9. San Miguel, J.F.; Schlag, R.; Khuageva, N.K.; Dimopoulos, M.A.; Shpilberg, O.; Kropff, M.; Spicka, I.; Petrucci, M.T.; Palumbo, A.; Samoilova, O.S.; et al. Bortezomib plus melphalan and prednisone for initial treatment of multiple myeloma. N. Engl. J. Med. 2008, 359, 906-917. [CrossRef] [PubMed]

10. Richardson, P.G.; Sonneveld, P.; Schuster, M.W.; Irwin, D.; Stadtmauer, E.A.; Facon, T.; Harousseau, J.L.; Ben-Yehuda, D.; Lonial, S.; Goldschmidt, H.; et al. Bortezomib or high-dose dexamethasone for relapsed multiple myeloma. N. Engl. J. Med. 2005, 352, 2487-2498. [CrossRef] [PubMed]

11. Usmani, S.; Ahmadi, T.; Ng, Y.; Lam, A.; Potlur, R.; Mehra, M. Analyses of real world data on overall survival in multiple myeloma patients with at least 3 prior lines of therapy including a PI and an IMiD, or double refractory to a PI and an IMiD. Blood 2015, 126, 4498.

12. Nooka, A.K.; Kastritis, E.; Dimopoulos, M.A.; Lonial, S. Treatment options for relapsed and refractory multiple myeloma. Blood 2015, 125, 3085-3099. [CrossRef] [PubMed]

13. Sonneveld, P.; Avet-Loiseau, H.; Lonial, S.; Usmani, S.; Siegel, D.; Anderson, K.C.; Chng, W.J.; Moreau, P.; Attal, M.; Kyle, R.A.; et al. Treatment of multiple myeloma with high-risk cytogenetics: A consensus of the International Myeloma Working Group. Blood 2016, 127, 2955-2962. [CrossRef] [PubMed]

14. Raja, K.R.; Kovarova, L.; Hajek, R. Review of phenotypic markers used in flow cytometric analysis of MGUS and MM, and applicability of flow cytometry in other plasma cell disorders. Br. J. Haematol. 2010, 149, 334-351. [CrossRef] [PubMed]

15. Tembhare, P.R.; Yuan, C.M.; Venzon, D.; Braylan, R.; Korde, N.; Manasanch, E.; Zuchlinsky, D.; Calvo, K.; Kurlander, R.; Bhutani, M.; et al. Flow cytometric differentiation of abnormal and normal plasma cells in the bone marrow in patients with multiple myeloma and its precursor diseases. Leuk. Res. 2014, 38, 371-376. [CrossRef] [PubMed]

16. Muccio, V.E.; Saraci, E.; Gilestro, M.; Gattei, V.; Zucchetto, A.; Astolfi, M.; Ruggeri, M.; Marzanati, E.; Passera, R.; Palumbo, A.; et al. Multiple myeloma: New surface antigens for the characterization of plasma cells in the era of novel agents. Cytom. B Clin. Cytom. 2016, 90, 81-90. [CrossRef] [PubMed]

17. Lokhorst, H.M.; Plesner, T.; Laubach, J.P.; Nahi, H.; Gimsing, P.; Hansson, M.; Minnema, M.C.; Lassen, U.; Krejcik, J.; Palumbo, A.; et al. Targeting CD38 with Daratumumab Monotherapy in Multiple Myeloma. N. Engl. J. Med. 2015, 373, 1207-1219. [CrossRef] [PubMed] 
18. Lonial, S.; Weiss, B.M.; Usmani, S.Z.; Singhal, S.; Chari, A.; Bahlis, N.J.; Belch, A.; Krishnan, A.; Vescio, R.A.; Mateos, M.V.; et al. Daratumumab monotherapy in patients with treatment-refractory multiple myeloma (SIRIUS): An open-label, randomised, phase 2 trial. Lancet 2016, 387, 1551-1560. [CrossRef]

19. Usmani, S.Z.; Weiss, B.M.; Plesner, T.; Bahlis, N.J.; Belch, A.; Lonial, S.; Lokhorst, H.M.; Voorhees, P.M.; Richardson, P.G.; Chari, A.; et al. Clinical efficacy of daratumumab monotherapy in patients with heavily pretreated relapsed or refractory multiple myeloma. Blood 2016, 128, 37-44. [CrossRef] [PubMed]

20. Palumbo, A.; Chanan-Khan, A.; Weisel, K.; Nooka, A.K.; Masszi, T.; Beksac, M.; Spicka, I.; Hungria, V.; Munder, M.; Mateos, M.V.; et al. Daratumumab, Bortezomib, and Dexamethasone for Multiple Myeloma. N. Engl. J. Med. 2016, 375, 754-766. [CrossRef] [PubMed]

21. Spencer, A.; Lentzsch, S.; Weisel, K.; Avet-Loiseau, H.; Mark, T.M.; Spicka, I.; Masszi, T.; Lauri, B.; Levin, M.D.; Bosi, A.; et al. Daratumumab plus bortezomib and dexamethasone versus bortezomib and dexamethasone in relapsed or refractory multiple myeloma: Updated analysis of CASTOR. Haematologica 2018. [CrossRef] [PubMed]

22. Dimopoulos, M.A.; Oriol, A.; Nahi, H.; San-Miguel, J.; Bahlis, N.J.; Usmani, S.Z.; Rabin, N.; Orlowski, R.Z.; Komarnicki, M.; Suzuki, K.; et al. Daratumumab, Lenalidomide, and Dexamethasone for Multiple Myeloma. N. Engl. J. Med. 2016, 375, 1319-1331. [CrossRef] [PubMed]

23. Dimopoulos, M.A.; San-Miguel, J.; Belch, A.; White, D.; Benboubker, L.; Cook, G.; Leiba, M.; Morton, J.; Ho, P.J.; Kim, K.; et al. Daratumumab plus lenalidomide and dexamethasone versus lenalidomide and dexamethasone in relapsed or refractory multiple myeloma: Updated analysis of POLLUX. Haematologica 2018. [CrossRef] [PubMed]

24. Zonder, J.A.; Mohrbacher, A.F.; Singhal, S.; van Rhee, F.; Bensinger, W.I.; Ding, H.; Fry, J.; Afar, D.E.; Singhal, A.K. A phase 1, multicenter, open-label, dose escalation study of elotuzumab in patients with advanced multiple myeloma. Blood 2012, 120, 552-559. [CrossRef] [PubMed]

25. Lonial, S.; Vij, R.; Harousseau, J.L.; Facon, T.; Moreau, P.; Mazumder, A.; Kaufman, J.L.; Leleu, X.; Tsao, L.C.; Westland, C.; et al. Elotuzumab in combination with lenalidomide and low-dose dexamethasone in relapsed or refractory multiple myeloma. J. Clin. Oncol. 2012, 30, 1953-1959. [CrossRef] [PubMed]

26. Lonial, S.; Dimopoulos, M.; Palumbo, A.; White, D.; Grosicki, S.; Spicka, I.; Walter-Croneck, A.; Moreau, P.; Mateos, M.V.; Magen, H.; et al. Elotuzumab Therapy for Relapsed or Refractory Multiple Myeloma. N. Engl. J. Med. 2015, 373, 621-631. [CrossRef] [PubMed]

27. Dimopoulos, M.A.; Lonial, S.; White, D.; Moreau, P.; Palumbo, A.; San-Miguel, J.; Shpilberg, O.; Anderson, K.; Grosicki, S.; Spicka, I.; et al. Elotuzumab plus lenalidomide/dexamethasone for relapsed or refractory multiple myeloma: ELOQUENT-2 follow-up and post-hoc analyses on progression-free survival and tumour growth. Br. J. Haematol. 2017, 178, 896-905. [CrossRef] [PubMed]

28. Dimopoulos, M.A.; Lonial, S.; Betts, K.A.; Chen, C.; Zichlin, M.L.; Brun, A.; Signorovitch, J.E.; Makenbaeva, D.; Mekan, S.; Sy, O.; et al. Elotuzumab Plus Lenalidomide and Dexamethasone in Relapsed/Refractory Multiple Myeloma: Extended 4-Year Follow-Up and Analysis of Relative Progression-Free Survival From the Randomized ELOQUENT-2 Trial. Cancer 2018. [CrossRef] [PubMed]

29. Voorhees, P.M.; Manges, R.F.; Sonneveld, P.; Jagannath, S.; Somlo, G.; Krishnan, A.; Lentzsch, S.; Frank, R.C.; Zweegman, S.; Wijermans, P.W.; et al. A phase 2 multicentre study of siltuximab, an anti-interleukin-6 monoclonal antibody, in patients with relapsed or refractory multiple myeloma. Br. J. Haematol. 2013, 161, 357-366. [CrossRef] [PubMed]

30. San-Miguel, J.; Blade, J.; Shpilberg, O.; Grosicki, S.; Maloisel, F.; Min, C.K.; Polo Zarzuela, M.; Robak, T.; Prasad, S.V.; Tee Goh, Y.; et al. Phase 2 randomized study of bortezomib-melphalan-prednisone with or without siltuximab (anti-IL-6) in multiple myeloma. Blood 2014, 123, 4136-4142. [CrossRef] [PubMed]

31. Bensinger, W.; Maziarz, R.T.; Jagannath, S.; Spencer, A.; Durrant, S.; Becker, P.S.; Ewald, B.; Bilic, S.; Rediske, J.; Baeck, J.; et al. A phase 1 study of lucatumumab, a fully human anti-CD40 antagonist monoclonal antibody administered intravenously to patients with relapsed or refractory multiple myeloma. Br. J. Haematol. 2012, 159, 58-66. [CrossRef] [PubMed]

32. Hussein, M.; Berenson, J.R.; Niesvizky, R.; Munshi, N.; Matous, J.; Sobecks, R.; Harrop, K.; Drachman, J.G.; Whiting, N. A phase I multidose study of dacetuzumab (SGN-40; humanized anti-CD40 monoclonal antibody) in patients with multiple myeloma. Haematologica 2010, 95, 845-848. [CrossRef] [PubMed] 
33. Agura, E.; Niesvizky, R.; Matous, J.; Munshi, N.; Hussein, M.; Parameswaran, R.V.; Tarantolo, S.; Whiting, N.C.; Drachman, J.G.; Zonder, J.A. Dacetuzumab (SGN-40), Lenalidomide, and Weekly Dexamethasone in Relapsed or Refractory Multiple Myeloma: Multiple Responses Observed in a Phase 1b Study. Blood 2009, 114, 2870.

34. Benson, D.M., Jr.; Hofmeister, C.C.; Padmanabhan, S.; Suvannasankha, A.; Jagannath, S.; Abonour, R.; Bakan, C.; Andre, P.; Efebera, Y.; Tiollier, J.; et al. A phase 1 trial of the anti-KIR antibody IPH2101 in patients with relapsed/refractory multiple myeloma. Blood 2012, 120, 4324-4333. [CrossRef] [PubMed]

35. Benson, D.M., Jr.; Cohen, A.D.; Jagannath, S.; Munshi, N.C.; Spitzer, G.; Hofmeister, C.C.; Efebera, Y.A.; Andre, P.; Zerbib, R.; Caligiuri, M.A. A Phase I Trial of the Anti-KIR Antibody IPH2101 and Lenalidomide in Patients with Relapsed/Refractory Multiple Myeloma. Clin. Cancer Res. 2015, 21, 4055-4061. [CrossRef] [PubMed]

36. Von Tresckow, B.; Boell, B.; Eichenauer, D.; Beschorner, D.; Knop, S.; Goebeler, M.E.; Chemnitz, J.M.; Hallek, M.; Engert, A.; Huebel, K. Anti-epidermal growth factor receptor antibody cetuximab in refractory or relapsed multiple myeloma: A phase II prospective clinical trial. Leukemia Lymphoma 2014, 55, $695-697$. [CrossRef] [PubMed]

37. Lesokhin, A.M.; Ansell, S.M.; Armand, P.; Scott, E.C.; Halwani, A.; Gutierrez, M.; Millenson, M.M.; Cohen, A.D.; Schuster, S.J.; Lebovic, D.; et al. Nivolumab in Patients with Relapsed or Refractory Hematologic Malignancy: Preliminary Results of a Phase Ib Study. J. Clin. Oncol. 2016, 34, 2698-2704. [CrossRef] [PubMed]

38. Badros, A.; Hyjek, E.; Ma, N.; Lesokhin, A.; Dogan, A.; Rapoport, A.P.; Kocoglu, M.; Lederer, E.; Philip, S.; Milliron, T.; et al. Pembrolizumab, pomalidomide, and low-dose dexamethasone for relapsed/refractory multiple myeloma. Blood 2017, 130, 1189-1197. [CrossRef] [PubMed]

39. Mateos, M.V.; Orlowski, R.Z.; DiCapua Siegel, D.S.; Reece, D.E.; Moreau, P.; Ocio, E.M.; Shah, J.J.; Rodríguez-Otero, P.; Munshi, N.C.; Avigan, D.; et al. Pembrolizumab in combination with lenalidomide and low-dose dexamethasone for relapsed/refractory multiple myeloma (RRMM): Final efficacy and safety analysis. J. Clin. Oncol. 2016, 34, 8010. [CrossRef]

40. FDA Alerts Healthcare Professionals and Oncology Clinical Investigators about Two Clinical Trials on Hold Evaluating KEYTRUDA®(Pembrolizumab) in Patients with Multiple Myeloma, 2017 ed.; U.S. Food and Drug Administration: Silver Spring, MD, USA, 20 September 2017.

41. Guillerey, C.; Harjunpaa, H.; Carrie, N.; Kassem, S.; Teo, T.; Miles, K.; Krumeich, S.; Weulersse, M.; Cuisinier, M.; Stannard, K.; et al. TIGIT immune checkpoint blockade restores CD8(+) T cell immunity against multiple myeloma. Blood 2018. [CrossRef] [PubMed]

42. Minnie, S.A.; Kuns, R.D.; Gartlan, K.H.; Zhang, P.; Wilkinson, A.N.; Samson, L.; Guillerey, C.; Engwerda, C.; MacDonald, K.P.A.; Smyth, M.J.; et al. Myeloma-escape after stem cell transplantation is a consequence of T cell exhaustion and is prevented by TIGIT blockade. Blood 2018. [CrossRef] [PubMed]

43. Trudel, S.; Lendvai, N.; Popat, R.; Voorhees, P.M.; Reeves, B.; Libby, E.N.; Richardson, P.; Anderson, L.; Sutherland, H.; Yong, K.; et al. Deep and Durable Responses in Patients (Pts) with Relapsed/Refractory Multiple Myeloma (MM) Treated with Monotherapy GSK2857916, an Antibody Drug Conjugate Against B-Cell Maturation Antigen (BCMA): Preliminary Results from Part 2 of Study BMA117159. Blood 2017, 130, 741.

44. Ko, J.; Breunig, C.; Figueroa, V.; Lehners, N.; Baumann, A.; Pálfi, A.; Müller, C.; Lutz, C.; Hechler, T.; Kulke, M.; et al. Preclinical Evaluation of Hdp-101, a Novel Anti-BCMA Antibody-Drug Conjugate, in Multiple Myeloma. Blood 2017, 130, 3070.

45. Kinneer, K.; Meekin, J.; Varkey, R.; Xiao, X.; Zhong, H.; Breen, S.; Hurt, E.; Thomas, S.; Flynn, M.; Hynes, P.; et al. Preclinical Evaluation of MEDI2228, a BCMA-Targeting Pyrrolobenzodiazepine-Linked Antibody Drug Conjugate for the Treatment of Multiple Myeloma. Blood 2017, 130, 3153.

46. Chanan-Khan, A.; Wolf, J.L.; Garcia, J.; Gharibo, M.; Jagannath, S.; Manfredi, D.; Sher, T.; Martin, C.; Zildjian, S.H.; O'Leary, J.; et al. Efficacy Analysis from Phase I Study of Lorvotuzumab Mertansine (IMGN901), Used as Monotherapy, In Patients with Heavily Pre-Treated CD56-Positive Multiple Myeloma-A Preliminary Efficacy Analysis. Blood 2010, 116, 1962.

47. Berdeja, J.G. Lorvotuzumab mertansine: Antibody-drug-conjugate for CD56+ multiple myeloma. Front. Biosci. 2014, 19, 163-170. [CrossRef]

48. Heffner, L.T.; Jagannath, S.; Zimmerman, T.M.; Lee, K.P.; Rosenblatt, J.; Lonial, S.; Lutz, R.J.; Czeloth, N.; Osterroth, F.; Ruehle, M.; et al. BT062, an Antibody-Drug Conjugate Directed Against CD138, Given Weekly for 3 Weeks in Each 4 Week Cycle: Safety and Further Evidence of Clinical Activity. Blood 2012, 120, 4042. 
49. Schonfeld, K.; Zuber, C.; Pinkas, J.; Hader, T.; Bernoster, K.; Uherek, C. Indatuximab ravtansine (BT062) combination treatment in multiple myeloma: Pre-clinical studies. J. Hematol. Oncol. 2017, 10, 13. [CrossRef] [PubMed]

50. Hipp, S.; Tai, Y.T.; Blanset, D.; Deegen, P.; Wahl, J.; Thomas, O.; Rattel, B.; Adam, P.J.; Anderson, K.C.; Friedrich, M. A novel BCMA/CD3 bispecific T-cell engager for the treatment of multiple myeloma induces selective lysis in vitro and in vivo. Leukemia 2017, 31, 1743-1751. [CrossRef] [PubMed]

51. Seckinger, A.; Delgado, J.A.; Moser, S.; Moreno, L.; Neuber, B.; Grab, A.; Lipp, S.; Merino, J.; Prosper, F.; Emde, M.; et al. Target Expression, Generation, Preclinical Activity, and Pharmacokinetics of the BCMA-T Cell Bispecific Antibody EM801 for Multiple Myeloma Treatment. Cancer Cell 2017, 31, 396-410. [CrossRef] [PubMed]

52. Girgis, S.; Shetty, S.; Jiao, T.; Amuzie, C.; Weinstock, D.; Watson, R.G.; Ford, J.; Pillarisetti, K.; Baldwin, E.; Bellew, K. Exploratory Pharmacokinetic/Pharmacodynamic and Tolerability Study of BCMAxCD3 in Cynomolgus Monkeys. Blood 2016, 128, 5668.

53. Zou, J.; Chen, D.; Zong, Y.; Ye, S.; Tang, J.; Meng, H.; An, G.; Zhang, X.; Yang, L. Immunotherapy based on bispecific T-cell engager with hIgG1 Fc sequence as a new therapeutic strategy in multiple myeloma. Cancer Sci. 2015, 106, 512-521. [CrossRef] [PubMed]

54. Chan, W.K.; Kang, S.; Youssef, Y.; Glankler, E.N.; Barrett, E.R.; Carter, A.M.; Ahmed, E.H.; Prasad, A.; Chen, L.; Zhang, J.; et al. A CS1-NKG2D Bispecific Antibody Collectively Activates Cytolytic Immune Cells against Multiple Myeloma. Cancer Immunol. Res. 2018, 6, 776-787. [CrossRef] [PubMed]

55. Ramadoss, N.S.; Schulman, A.D.; Choi, S.H.; Rodgers, D.T.; Kazane, S.A.; Kim, C.H.; Lawson, B.R.; Young, T.S. An anti-B cell maturation antigen bispecific antibody for multiple myeloma. J. Am. Chem. Soc. 2015, 137, 5288-5291. [CrossRef] [PubMed]

56. Ali, S.A.; Shi, V.; Maric, I.; Wang, M.; Stroncek, D.F.; Rose, J.J.; Brudno, J.N.; Stetler-Stevenson, M.; Feldman, S.A.; Hansen, B.G.; et al. T cells expressing an anti-B-cell maturation antigen chimeric antigen receptor cause remissions of multiple myeloma. Blood 2016, 128, 1688-1700. [CrossRef] [PubMed]

57. Brudno, J.N.; Maric, I.; Hartman, S.D.; Rose, J.J.; Wang, M.; Lam, N.; Stetler-Stevenson, M.; Salem, D.; Yuan, C.; Pavletic, S.; et al. T Cells Genetically Modified to Express an Anti-B-Cell Maturation Antigen Chimeric Antigen Receptor Cause Remissions of Poor-Prognosis Relapsed Multiple Myeloma. J. Clin. Oncol. 2018, 36, 2267-2280. [CrossRef] [PubMed]

58. Berdeja, J.G.; Lin, Y.; Raje, N.S.; Siegel, D.S.D.; Munshi, N.C.; Liedtke, M.; Jagannath, S.; Maus, M.V.; Turka, A.; Lam, L.P.; et al. First-in-human multicenter study of bb2121 anti-BCMA CAR T-cell therapy for relapsed/refractory multiple myeloma: Updated results. J. Clin. Oncol. 2017, 35, 3010. [CrossRef]

59. Fan, F.; Zhao, W.; Liu, J.; He, A.; Chen, Y.; Cao, X.; Yang, N.; Wang, B.; Zhang, P.; Zhang, Y.; et al. Durable remissions with BCMA-specific chimeric antigen receptor (CAR)-modified $\mathrm{T}$ cells in patients with refractory/relapsed multiple myeloma. J. Clin. Oncol. 2017, 35, LBA3001. [CrossRef]

60. Cohen, A.D.; Garfall, A.L.; Stadtmauer, E.A.; Lacey, S.F.; Lancaster, E.; Vogl, D.T.; Weiss, B.M.; Ambrose, D.E.; Nelson, A.M.; Chen, F.; et al. Safety and Efficacy of B-Cell Maturation Antigen (BCMA)-Specific Chimeric Antigen Receptor T Cells (CART-BCMA) with Cyclophosphamide Conditioning for Refractory Multiple Myeloma (MM). Blood 2017, 130, 505.

61. Lee, L.; Draper, B.; Chaplin, N.; Philip, B.; Chin, M.; Galas-Filipowicz, D.; Onuoha, S.; Thomas, S.; Baldan, V.; Bughda, R.; et al. An APRIL-based chimeric antigen receptor for dual targeting of BCMA and TACI in multiple myeloma. Blood 2018, 131, 746-758. [CrossRef] [PubMed]

62. Garfall, A.L.; Maus, M.V.; Hwang, W.T.; Lacey, S.F.; Mahnke, Y.D.; Melenhorst, J.J.; Zheng, Z.; Vogl, D.T.; Cohen, A.D.; Weiss, B.M.; et al. Chimeric Antigen Receptor T Cells against CD19 for Multiple Myeloma. N. Engl. J. Med. 2015, 373, 1040-1047. [CrossRef] [PubMed]

63. Garfall, A.L.; Stadtmauer, E.A.; Hwang, W.T.; Lacey, S.F.; Melenhorst, J.J.; Krevvata, M.; Carroll, M.P.; Matsui, W.H.; Wang, Q.; Dhodapkar, M.V.; et al. Anti-CD19 CAR T cells with high-dose melphalan and autologous stem cell transplantation for refractory multiple myeloma. JCI Insight 2018, 3. [CrossRef] [PubMed]

64. Guo, B.; Chen, M.; Han, Q.; Hui, F.; Dai, H.; Zhang, W.; Zhang, Y.; Wang, Y.; Zhu, H.; Han, W. CD138-directed adoptive immunotherapy of chimeric antigen receptor (CAR)-modified T cells for multiple myeloma. J. Cell. Immunother. 2016, 2, 28-35. [CrossRef] 
65. Drent, E.; Themeli, M.; Poels, R.; de Jong-Korlaar, R.; Yuan, H.; de Bruijn, J.; Martens, A.C.M.; Zweegman, S.; van de Donk, N.; Groen, R.W.J.; et al. A Rational Strategy for Reducing On-Target Off-Tumor Effects of CD38-Chimeric Antigen Receptors by Affinity Optimization. Mol. Ther. 2017, 25, 1946-1958. [CrossRef] [PubMed]

66. Drent, E.; Groen, R.W.; Noort, W.A.; Themeli, M.; Lammerts van Bueren, J.J.; Parren, P.W.; Kuball, J.; Sebestyen, Z.; Yuan, H.; de Bruijn, J.; et al. Pre-clinical evaluation of CD38 chimeric antigen receptor engineered $\mathrm{T}$ cells for the treatment of multiple myeloma. Haematologica 2016, 101, 616-625. [CrossRef] [PubMed]

67. Casucci, M.; Nicolis di Robilant, B.; Falcone, L.; Camisa, B.; Norelli, M.; Genovese, P.; Gentner, B.; Gullotta, F.; Ponzoni, M.; Bernardi, M.; et al. CD44v6-targeted T cells mediate potent antitumor effects against acute myeloid leukemia and multiple myeloma. Blood 2013, 122, 3461-3472. [CrossRef] [PubMed]

68. Hosen, N.; Matsunaga, Y.; Hasegawa, K.; Matsuno, H.; Nakamura, Y.; Makita, M.; Watanabe, K.; Yoshida, M.; Satoh, K.; Morimoto, S.; et al. The activated conformation of integrin beta7 is a novel multiple myeloma-specific target for CAR T cell therapy. Nat. Med. 2017, 23, 1436-1443. [CrossRef] [PubMed]

69. Chu, J.; He, S.; Deng, Y.; Zhang, J.; Peng, Y.; Hughes, T.; Yi, L.; Kwon, C.H.; Wang, Q.E.; Devine, S.M.; et al. Genetic modification of T cells redirected toward CS1 enhances eradication of myeloma cells. Clin. Cancer Res. 2014, 20, 3989-4000. [CrossRef] [PubMed]

70. Wang, X.; Walter, M.; Urak, R.; Weng, L.; Huynh, C.; Lim, L.; Wong, C.W.; Chang, W.C.; Thomas, S.H.; Sanchez, J.F.; et al. Lenalidomide Enhances the Function of CS1 Chimeric Antigen Receptor-Redirected T Cells Against Multiple Myeloma. Clin. Cancer Res. 2018, 24, 106-119. [CrossRef] [PubMed]

71. De Weers, M.; Tai, Y.T.; van der Veer, M.S.; Bakker, J.M.; Vink, T.; Jacobs, D.C.; Oomen, L.A.; Peipp, M.; Valerius, T.; Slootstra, J.W.; et al. Daratumumab, a novel therapeutic human CD38 monoclonal antibody, induces killing of multiple myeloma and other hematological tumors. J. Immunol. 2011, 186, 1840-1848. [CrossRef] [PubMed]

72. Overdijk, M.B.; Verploegen, S.; Bogels, M.; van Egmond, M.; Lammerts van Bueren, J.J.; Mutis, T.; Groen, R.W.; Breij, E.; Martens, A.C.; Bleeker, W.K.; et al. Antibody-mediated phagocytosis contributes to the anti-tumor activity of the therapeutic antibody daratumumab in lymphoma and multiple myeloma. MAbs 2015, 7, 311-321. [CrossRef] [PubMed]

73. McKeage, K. Daratumumab: First Global Approval. Drugs 2016, 76, 275-281. [CrossRef] [PubMed]

74. Luo, X.W.; Du, X.Q.; Li, J.L.; Liu, X.P.; Meng, X.Y. Treatment options for refractory/relapsed multiple myeloma: An updated evidence synthesis by network meta-analysis. Cancer Manag. Res. 2018, 10, 2817-2823. [CrossRef] [PubMed]

75. Krejcik, J.; Frerichs, K.A.; Nijhof, I.S.; van Kessel, B.; van Velzen, J.F.; Bloem, A.C.; Broekmans, M.E.C.; Zweegman, S.; van Meerloo, J.; Musters, R.J.P.; et al. Monocytes and Granulocytes Reduce CD38 Expression Levels on Myeloma Cells in Patients Treated with Daratumumab. Clin. Cancer Res. 2017, 23, 7498-7511. [CrossRef] [PubMed]

76. Chillemi, A.; Quarona, V.; Zito, A.; Morandi, F.; Marimpietri, D.; Cuccioloni, M.; Robert, O.J.; Mark, C.S.; Bolzoni, M.; Toscani, D.; et al. Generation and Characterization of Microvesicles after Daratumumab Interaction with Myeloma Cells. Blood 2015, 126, 1849.

77. Morandi, F.; Marimpietri, D.; Horenstein, A.L.; Bolzoni, M.; Toscani, D.; Costa, F.; Castella, B.; Faini, A.C.; Massaia, M.; Pistoia, V.; et al. Microvesicles released from multiple myeloma cells are equipped with ectoenzymes belonging to canonical and non-canonical adenosinergic pathways and produce adenosine from ATP and NAD+. Oncoimmunology 2018, 7, e1458809. [CrossRef] [PubMed]

78. Veillette, A.; Guo, H. CS1, a SLAM family receptor involved in immune regulation, is a therapeutic target in multiple myeloma. Crit. Rev. Oncol. Hematol. 2013, 88, 168-177. [CrossRef] [PubMed]

79. Hsi, E.D.; Steinle, R.; Balasa, B.; Szmania, S.; Draksharapu, A.; Shum, B.P.; Huseni, M.; Powers, D.; Nanisetti, A.; Zhang, Y.; et al. CS1, a potential new therapeutic antibody target for the treatment of multiple myeloma. Clin. Cancer Res. 2008, 14, 2775-2784. [CrossRef] [PubMed]

80. Cruz-Munoz, M.E.; Dong, Z.; Shi, X.; Zhang, S.; Veillette, A. Influence of CRACC, a SLAM family receptor coupled to the adaptor EAT-2, on natural killer cell function. Nat. Immunol. 2009, 10, 297-305. [CrossRef] [PubMed] 
81. Tai, Y.T.; Dillon, M.; Song, W.; Leiba, M.; Li, X.F.; Burger, P.; Lee, A.I.; Podar, K.; Hideshima, T.; Rice, A.G.; et al. Anti-CS1 humanized monoclonal antibody HuLuc63 inhibits myeloma cell adhesion and induces antibody-dependent cellular cytotoxicity in the bone marrow milieu. Blood 2008, 112, 1329-1337. [CrossRef] [PubMed]

82. Collins, S.M.; Bakan, C.E.; Swartzel, G.D.; Hofmeister, C.C.; Efebera, Y.A.; Kwon, H.; Starling, G.C.; Ciarlariello, D.; Bhaskar, S.; Briercheck, E.L.; et al. Elotuzumab directly enhances NK cell cytotoxicity against myeloma via CS1 ligation: Evidence for augmented NK cell function complementing ADCC. Cancer Immunol. Immunother. CII 2013, 62, 1841-1849. [CrossRef] [PubMed]

83. Kurdi, A.T.; Glavey, S.V.; Bezman, N.A.; Jhatakia, A.; Guerriero, J.L.; Manier, S.; Moschetta, M.; Mishima, Y.; Roccaro, A.; Detappe, A.; et al. Antibody-Dependent Cellular Phagocytosis by Macrophages is a Novel Mechanism of Action of Elotuzumab. Mol. Cancer Ther. 2018, 17, 1454-1463. [CrossRef] [PubMed]

84. Markham, A. Elotuzumab: First Global Approval. Drugs 2016, 76, 397-403. [CrossRef] [PubMed]

85. U.S. Food and Drug Administration. Elotuzumab [Media Release], 30 November 2015.

86. Madry, C.; Laabi, Y.; Callebaut, I.; Roussel, J.; Hatzoglou, A.; Le Coniat, M.; Mornon, J.P.; Berger, R.; Tsapis, A. The characterization of murine BCMA gene defines it as a new member of the tumor necrosis factor receptor superfamily. Int. Immunol. 1998, 10, 1693-1702. [CrossRef] [PubMed]

87. O'Connor, B.P.; Raman, V.S.; Erickson, L.D.; Cook, W.J.; Weaver, L.K.; Ahonen, C.; Lin, L.L.; Mantchev, G.T.; Bram, R.J.; Noelle, R.J. BCMA is essential for the survival of long-lived bone marrow plasma cells. J. Exp. Med. 2004, 199, 91-98. [CrossRef] [PubMed]

88. Tai, Y.T.; Mayes, P.A.; Acharya, C.; Zhong, M.Y.; Cea, M.; Cagnetta, A.; Craigen, J.; Yates, J.; Gliddon, L.; Fieles, W.; et al. Novel anti-B-cell maturation antigen antibody-drug conjugate (GSK2857916) selectively induces killing of multiple myeloma. Blood 2014, 123, 3128-3138. [CrossRef] [PubMed]

89. Voorhees, P.M.; Chen, Q.; Small, G.W.; Kuhn, D.J.; Hunsucker, S.A.; Nemeth, J.A.; Orlowski, R.Z. Targeted inhibition of interleukin-6 with CNTO 328 sensitizes pre-clinical models of multiple myeloma to dexamethasone-mediated cell death. Br. J. Haematol. 2009, 145, 481-490. [CrossRef] [PubMed]

90. Sahara, N.; Takeshita, A.; Shigeno, K.; Fujisawa, S.; Takeshita, K.; Naito, K.; Ihara, M.; Ono, T.; Tamashima, S.; Nara, K.; et al. Clinicopathological and prognostic characteristics of CD56-negative multiple myeloma. Br. J. Haematol. 2002, 117, 882-885. [CrossRef] [PubMed]

91. Palaiologou, M.; Delladetsima, I.; Tiniakos, D. CD138 (syndecan-1) expression in health and disease. Histol. Histopathol. 2014, 29, 177-189. [CrossRef] [PubMed]

92. Ikeda, H.; Hideshima, T.; Fulciniti, M.; Lutz, R.J.; Yasui, H.; Okawa, Y.; Kiziltepe, T.; Vallet, S.; Pozzi, S.; Santo, L.; et al. The monoclonal antibody nBT062 conjugated to cytotoxic Maytansinoids has selective cytotoxicity against CD138-positive multiple myeloma cells in vitro and in vivo. Clin. Cancer Res. 2009, 15, 4028-4037. [CrossRef] [PubMed]

93. Fichou, N.; Gouard, S.; Maurel, C.; Barbet, J.; Ferrer, L.; Morgenstern, A.; Bruchertseifer, F.; Faivre-Chauvet, A.; Bigot-Corbel, E.; Davodeau, F.; et al. Single-Dose Anti-CD138 Radioimmunotherapy: Bismuth-213 is More Efficient than Lutetium-177 for Treatment of Multiple Myeloma in a Preclinical Model. Front. Med. 2015, 2, 76. [CrossRef] [PubMed]

94. Lanier, L.L. Up on the tightrope: Natural killer cell activation and inhibition. Nat. Immunol. 2008, 9, 495-502. [CrossRef] [PubMed]

95. Baeuerle, P.A.; Reinhardt, C. Bispecific T-cell engaging antibodies for cancer therapy. Cancer Res. 2009, 69, 4941-4944. [CrossRef] [PubMed]

96. Littman, D.R. Releasing the Brakes on Cancer Immunotherapy. Cell 2015, 162, 1186-1190. [CrossRef] [PubMed]

97. Ribas, A. Releasing the Brakes on Cancer Immunotherapy. N. Engl. J. Med. 2015, 373, 1490-1492. [CrossRef] [PubMed]

98. Keytruda Approval History, 4 September 2014.

99. Opdivo Approval History, 22 December 2014.

100. Tecentriq Approval History, 18 May 2016.

101. Imfinzi Approval History, 1 May 2017.

102. Bavencio Approval History, 23 March 2017. 
103. Gorgun, G.; Samur, M.K.; Cowens, K.B.; Paula, S.; Bianchi, G.; Anderson, J.E.; White, R.E.; Singh, A.; Ohguchi, H.; Suzuki, R.; et al. Lenalidomide Enhances Immune Checkpoint Blockade-Induced Immune Response in Multiple Myeloma. Clin. Cancer Res. 2015, 21, 4607-4618. [CrossRef] [PubMed]

104. Jing, W.; Gershan, J.A.; Weber, J.; Tlomak, D.; McOlash, L.; Sabatos-Peyton, C.; Johnson, B.D. Combined immune checkpoint protein blockade and low dose whole body irradiation as immunotherapy for myeloma. J. Immunother. Cancer 2015, 3, 2. [CrossRef] [PubMed]

105. Shah, J.J.; Jagannath, S.; Mateos, M.-V.; Palumbo, A.; Kher, U.; Marinello, P.M.; Miguel, J.S. KEYNOTE-183: A randomized, open-label phase 3 study of pembrolizumab in combination with pomalidomide and low-dose dexamethasone in refractory or relapsed and refractory multiple myeloma (rrMM). J. Clin. Oncol. 2016, 34, TPS8070. [CrossRef]

106. Palumbo, A.; Mateos, M.-V.; Miguel, J.S.; Shah, J.; Thompson, S.; Marinello, P.M.; Jagannath, S. KEYNOTE-185: A randomized, open-label phase 3 study of pembrolizumab in combination with lenalidomide and low-dose dexamethasone in newly diagnosed and treatment-naive multiple myeloma (MM). J. Clin. Oncol. 2016, 34, TPS8069. [CrossRef]

107. Barrett, D.M.; Singh, N.; Porter, D.L.; Grupp, S.A.; June, C.H. Chimeric antigen receptor therapy for cancer. Annu. Rev. Med. 2014, 65, 333-347. [CrossRef] [PubMed]

108. Brentjens, R.J.; Davila, M.L.; Riviere, I.; Park, J.; Wang, X.; Cowell, L.G.; Bartido, S.; Stefanski, J.; Taylor, C.; Olszewska, M.; et al. CD19-targeted T cells rapidly induce molecular remissions in adults with chemotherapy-refractory acute lymphoblastic leukemia. Sci. Transl. Med. 2013, 5, 177ra138. [CrossRef] [PubMed]

109. Brentjens, R.J.; Riviere, I.; Park, J.H.; Davila, M.L.; Wang, X.; Stefanski, J.; Taylor, C.; Yeh, R.; Bartido, S.; Borquez-Ojeda, O.; et al. Safety and persistence of adoptively transferred autologous CD19-targeted T cells in patients with relapsed or chemotherapy refractory B-cell leukemias. Blood 2011, 118, 4817-4828. [CrossRef] [PubMed]

110. Davila, M.L.; Riviere, I.; Wang, X.; Bartido, S.; Park, J.; Curran, K.; Chung, S.S.; Stefanski, J.; Borquez-Ojeda, O.; Olszewska, M.; et al. Efficacy and toxicity management of 19-28z CAR T cell therapy in B cell acute lymphoblastic leukemia. Sci. Transl. Med. 2014, 6, 224ra225. [CrossRef] [PubMed]

111. Kochenderfer, J.N.; Dudley, M.E.; Kassim, S.H.; Somerville, R.P.; Carpenter, R.O.; Stetler-Stevenson, M.; Yang, J.C.; Phan, G.Q.; Hughes, M.S.; Sherry, R.M.; et al. Chemotherapy-refractory diffuse large B-cell lymphoma and indolent B-cell malignancies can be effectively treated with autologous T cells expressing an anti-CD19 chimeric antigen receptor. J. Clin. Oncol. 2015, 33, 540-549. [CrossRef] [PubMed]

112. Maude, S.L.; Frey, N.; Shaw, P.A.; Aplenc, R.; Barrett, D.M.; Bunin, N.J.; Chew, A.; Gonzalez, V.E.; Zheng, Z.; Lacey, S.F.; et al. Chimeric antigen receptor T cells for sustained remissions in leukemia. N. Engl. J. Med. 2014, 371, 1507-1517. [CrossRef] [PubMed]

113. Turtle, C.J.; Hanafi, L.A.; Berger, C.; Hudecek, M.; Pender, B.; Robinson, E.; Hawkins, R.; Chaney, C.; Cherian, S.; Chen, X.; et al. Immunotherapy of non-Hodgkin's lymphoma with a defined ratio of CD8+ and CD4+ CD19-specific chimeric antigen receptor-modified T cells. Sci. Transl. Med. 2016, 8, 355ra116. [CrossRef] [PubMed]

114. Wang, X.; Popplewell, L.L.; Wagner, J.R.; Naranjo, A.; Blanchard, M.S.; Mott, M.R.; Norris, A.P.; Wong, C.W.; Urak, R.Z.; Chang, W.C.; et al. Phase 1 studies of central memory-derived CD19 CAR T-cell therapy following autologous HSCT in patients with B-cell NHL. Blood 2016, 127, 2980-2990. [CrossRef] [PubMed]

115. Chang, Z.L.; Chen, Y.Y. CARs: Synthetic Immunoreceptors for Cancer Therapy and Beyond. Trends Mol. Med. 2017, 23, 430-450. [CrossRef] [PubMed]

116. Kochenderfer, J.N.; Feldman, S.A.; Zhao, Y.; Xu, H.; Black, M.A.; Morgan, R.A.; Wilson, W.H.; Rosenberg, S.A. Construction and preclinical evaluation of an anti-CD19 chimeric antigen receptor. J. Immunother. 2009, 32, 689-702. [CrossRef] [PubMed]

117. Sadelain, M. CAR therapy: The CD19 paradigm. J. Clin. Investig. 2015, 125, 3392-3400. [CrossRef] [PubMed]

118. Hay, K.A.; Hanafi, L.A.; Li, D.; Gust, J.; Liles, W.C.; Wurfel, M.M.; Lopez, J.A.; Chen, J.; Chung, D.; Harju-Baker, S.; et al. Kinetics and Biomarkers of Severe Cytokine Release Syndrome after CD19 Chimeric Antigen Receptor-modified T Cell Therapy. Blood 2017. [CrossRef] [PubMed]

119. Lorentzen, C.L.; Straten, P.T. CD19-Chimeric Antigen Receptor T Cells for Treatment of Chronic Lymphocytic Leukaemia and Acute Lymphoblastic Leukaemia. Scand. J. Immunol. 2015, 82, 307-319. [CrossRef] [PubMed] 
120. Maude, S.L.; Barrett, D.; Teachey, D.T.; Grupp, S.A. Managing cytokine release syndrome associated with novel T cell-engaging therapies. Cancer J. 2014, 20, 119-122. [CrossRef] [PubMed]

121. Carpenter, R.O.; Evbuomwan, M.O.; Pittaluga, S.; Rose, J.J.; Raffeld, M.; Yang, S.; Gress, R.E.; Hakim, F.T.; Kochenderfer, J.N. B-cell maturation antigen is a promising target for adoptive T-cell therapy of multiple myeloma. Clin. Cancer Res. 2013, 19, 2048-2060. [CrossRef] [PubMed]

122. Novak, A.J.; Darce, J.R.; Arendt, B.K.; Harder, B.; Henderson, K.; Kindsvogel, W.; Gross, J.A.; Greipp, P.R.; Jelinek, D.F. Expression of BCMA, TACI, and BAFF-R in multiple myeloma: A mechanism for growth and survival. Blood 2004, 103, 689-694. [CrossRef] [PubMed]

123. Berdeja, J.G.; Lin, Y.; Raje, N.; Munshi, N.; Siegel, D.; Liedtke, M.; Jagannath, S.; Maus, M.V.; Turka, A.; Lam, L.P.; et al. Durable Clinical Responses in Heavily Pretreated Patients with Relapsed/Refractory Multiple Myeloma: Updated Results from a Multicenter Study of bb2121 Anti-Bcma CAR T Cell Therapy. In Proceedings of American Society of Hematology. Blood 2017, 130, 740.

124. Neelapu, S.S.; Locke, F.L.; Bartlett, N.L.; Lekakis, L.J.; Miklos, D.B.; Jacobson, C.A.; Braunschweig, I.; Oluwole, O.O.; Siddiqi, T.; Lin, Y.; et al. Axicabtagene Ciloleucel CAR T-Cell Therapy in Refractory Large B-Cell Lymphoma. N. Engl. J. Med. 2017, 377, 2531-2544. [CrossRef] [PubMed]

125. Laurent, S.A.; Hoffmann, F.S.; Kuhn, P.H.; Cheng, Q.; Chu, Y.; Schmidt-Supprian, M.; Hauck, S.M.; Schuh, E.; Krumbholz, M.; Rubsamen, H.; et al. gamma-Secretase directly sheds the survival receptor BCMA from plasma cells. Nat. Commun. 2015, 6, 7333. [CrossRef] [PubMed]

126. Paiva, B.; Puig, N.; Cedena, M.T.; de Jong, B.G.; Ruiz, Y.; Rapado, I.; Martinez-Lopez, J.; Cordon, L.; Alignani, D.; Delgado, J.A.; et al. Differentiation stage of myeloma plasma cells: Biological and clinical significance. Leukemia 2017, 31, 382-392. [CrossRef] [PubMed]

127. Zoller, M. CD44: Can a cancer-initiating cell profit from an abundantly expressed molecule? Nat. Rev. Cancer 2011, 11, 254-267. [CrossRef] [PubMed]

128. Neu, S.; Geiselhart, A.; Sproll, M.; Hahn, D.; Kuci, S.; Niethammer, D.; Handgretinger, R. Expression of CD44 isoforms by highly enriched CD34-positive cells in cord blood, bone marrow and leukaphereses. Bone Marrow. Transplant. 1997, 20, 593-598. [CrossRef] [PubMed]

129. Senbanjo, L.T.; Chellaiah, M.A. CD44: A Multifunctional Cell Surface Adhesion Receptor Is a Regulator of Progression and Metastasis of Cancer Cells. Front. Cell Dev. Biol. 2017, 5, 18. [CrossRef] [PubMed] 